\title{
Chlorophyll $a$ and physical-chemical features of small water bodies as indicators of land use in the Wielkopolska region (Western Poland)
}

\author{
Natalia Kuczyńska-Kippen \& Tomasz Joniak*
}

Adam Mickiewicz University of Poznań, Faculty of Biology, Department of Water Protection, Umultowska str. 89, 61-614 Poznań, Poland

* Corresponding author: tjoniak@amu.edu.pl

Received: 9/12/08 Accepted: 24/6/09

\begin{abstract}
Chlorophyll $a$ and physical-chemical features of small water bodies as indicators of land use in the Wielkopolska region (Western Poland)

The present paper analyzes the impact of differentiated land uses in the catchment area (pastoreo, forest and urban) on changes in phytoplankton biomass of open water in small water bodies located in the central part of the Wielkopolska region (western Poland). Anthropogenic pressure in the pond surroundings ranged from almost negligible in the forested areas to very strong in the urban areas which were subject to the impact of the large city agglomeration. The examination of chlorophyll $a$ and the physical-chemical features of water were carried out over one week in July 2006. The water of the investigated ponds had a characteristically neutral to alkaline $\mathrm{pH}$ and moderate mineralization. Urban ponds exhibited the higher chlorophyll concentrations and $\mathrm{pH}$ values. Ponds in the pastoral landscape were characterized by high concentrations of phosphorus due to livestock influence. Some ponds in the pastoral area presented also high nitrate concentrations indicating agricultural influence. A specific feature of mid-forest ponds was a relatively lower concentration of phosphate in the water, but they had a high concentration of DOM, both factors were probably responsible for the maintenance of a low biomass of algae.
\end{abstract}

Key words: Ponds, anthropogenic pressure, chlorophyll $a$, water chemistry, DOM.

\section{RESUMEN}

Clorofila a y caracteríticas físicas y químicas de pequeñas masas de agua como indicadoras de los usos del suelo en la región de Wielkopolska (Polonia occidental)

El presente artículo analiza el impacto de los usos del suelo en la cuenca de captación (pastoral, forestal y urbano en los cambios de la biomasa fitoplanctónica de aguas abiertas en charcas ubicadas en la parte central de la región de Wielkopolska (Polonia occidental). La presión antropogénica en el entorno de las charcas fue de casi negligible en las zonas de bosque a muy intensa en las áreas urbanas que estaban sujetas al impacto de una gran aglomeración metropolitana. La determinación de la clorofila a y de las características físico-químicas del agua se realizó durante una semana en julio de 2006. El agua de las charcas investigadas tenía un pH de neutro a alcalino y una mineralización moderada. Las charcas urbanas presentaron los valores más altos de clorofila a y de $\mathrm{pH}$. Las charcas del área pastoral se distinguieron por las altas concentraciones de fósforo, debido a la influencia del ganado y algunas de ellas presentaban altos valores de nitratos, indicando también una influencia agrícola. Las charcas de la zona forestal se caracterizaron por una relativamente baja concentración de fosfato en el agua, pero con valores altos de DOM, ambos factores contribuyeron al mantenimiento de una biomasa baja de fitoplancton.

Palabras clave: Charcas, presión antropogénica, clorofila a, química de las aguas, materia orgánica disuelta (DOM). 


\section{INTRODUCTION}

The anthropogenic transformation of the catchment area may accelerate the nutrient enrichment of waters, and hence it creates concern, particularly, in degraded areas within urban and pastoral landscapes. This is particularly relevant in the case of small water bodies, which as small and shallow ecosystems are particularly prone to sudden changes of the water quality. Although large bodies of water are objects of permanent monitoring, in the case of small water bodies such examinations are often made randomly (Joniak et al., 2006). Interdisplinary examinations including the abiotic features and biotic structure of small water bodies have been carried out in Poland in recent years (Paczuska et al., 2002, Kuczyńska-Kippen, 2009), and one of the most important conclusions has been to indicate the vital role of anthropogenic degradation of the landscape on the functioning of such ecosystems. At the same time considerable restrictions were found regarding the possibility of usage of common systems of water trophy classification of small water bodies were found (Joniak et al., 2009).

Small water bodies create specific microecosystems with a visible and dynamic relationship between abiotic features of the environment and hydrobionts, especially algae (Prezelin $e t$ al., 1991). One of the methods for the estimation of the growth and development of the phytoplankton community is to perform an analysis of photosynthetic pigments, even though the content of chlorophyll in the cells changes with the availability of light (Wetzel, 2001) and thus with depth and trophic gradient (Kasprzak et al., 2008). The aim of this study was to find differences in the phytoplankton biomass and the physicalchemical features of the water in small water bodies according to different types of landscape: forest, pastoral and urban.

\section{MATERIAL AND METHODS}

According to the character of the landscape and land uses, the following types of water bodies were distinguished: typical mid-forest (group I), natural in an agricultural area (group II) and strongly antropogenically modified in the urban landscape (group III). The area of group I was characterised by a high degree of naturality, without traces of tree cutting or mechanical degradation of duff. In the group of the agricultural area there were intensively fertilised fields with root and cereal crops, as well as meadows for cattle pasturing. A feature characteristic of the urban areas was the strong degradation of the ground surface caused by mechanical levelling with heavy implements which lead to fallow lands.

The examination was carried out (once for each pond) during one week in July 2006 on 15 small water bodies, that had areas between 0.5 and 5 ha and were located in the central part of the Wielkopolska Lakeland. Most of the ponds were very shallow $(<1.0 \mathrm{~m})$, with the exception of three ponds (max. depth $1.5 \mathrm{~m}$ ). Field measurements: temperature, dissolved oxygen (DO), electric conductivity (EC), $\mathrm{pH}$, transparency with Secchi disc (SDV) and water samples for chemical analysis (in triplicate) were taken in the deepest part of the open water area ( 15 ponds, $n=45$ ) and at the same time of the day to avoid diurnal variation (8-10 am). Chlorophyll $a$ was determined after extraction in acetone. Dissolved or-

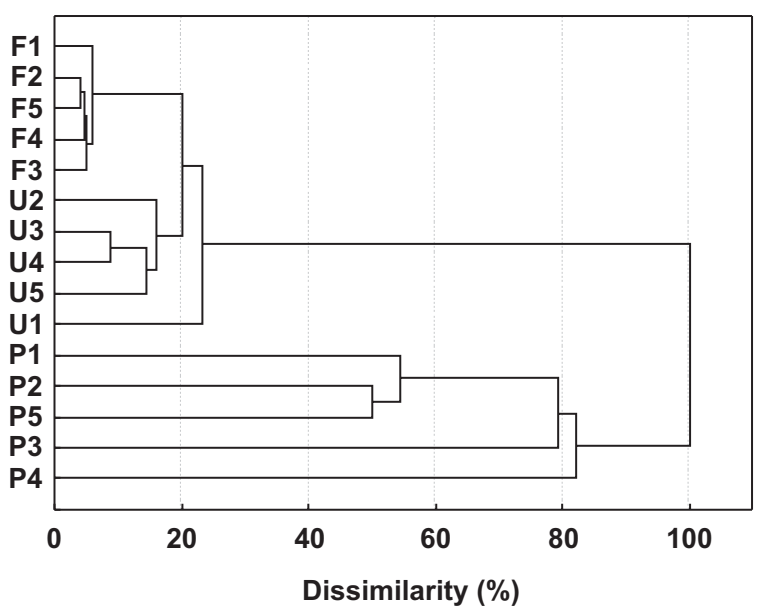

Figure 1. Tree diagram of pond groups ( $\mathrm{F}$ - forest, $\mathrm{P}-$ pastoral, $\mathrm{U}$ - urban) resulting from the cluster analysis with physical-chemical variables (complete linkage method with Manhattan distance). Dendrograma de los grupos de charcas ( $F$-forestal, $P$ - pastoral, $U$ - urbano) resultante del análisis de agrupamiento con las variables físicas y químicas (método de enlace completo con la distancia de Manhattan). 
Table 1. The physical-chemical water features (mean \pm SD) of the researched ponds of different types of landscape: forest (I), pastoral (II) and urban (III). Características físico-químicas del agua (media \pm SD) de las charcas investigadas en los distintos tipos paisajísticos: forestal (I), pastoral (II) y urbano (III).

\begin{tabular}{cccccccccc}
\hline Group of ponds & SDV m & DOM m & EC $\mu \mathrm{S} / \mathrm{cm}^{-1}$ & $\mathrm{pH}$ & Oxygen mg l & $\mathrm{TP} \mu \mathrm{g} \mathrm{P} l^{-1}$ & $\mathrm{TRP} \mu \mathrm{g} \mathrm{I}^{-1}$ & $\mathrm{NO}_{3} \mu \mathrm{g} \mathrm{l}^{-1}$ & $\mathrm{NH}_{4} \mu \mathrm{g} \mathrm{l}^{-1}$ \\
\hline I & $0.5 \pm 0.3$ & $9.4 \pm 5.4$ & $567 \pm 248$ & $7.1 \pm 0.2$ & $9.1 \pm 4.8$ & $62 \pm 28$ & $20 \pm 26$ & $578 \pm 400$ & $1720 \pm 460$ \\
II & $0.6 \pm 0.6$ & $9.6 \pm 8.2$ & $834 \pm 440$ & $8.1 \pm 0.7$ & $7.7 \pm 3.9$ & $336 \pm 302$ & $209 \pm 184$ & $1970 \pm 740$ & $1207 \pm 870$ \\
III & $0.8 \pm 0.5$ & $3.1 \pm 2.0$ & $677 \pm 407$ & $9.0 \pm 0.5$ & $10.2 \pm 2.9$ & $97 \pm 64$ & $42 \pm 61$ & $1050 \pm 860$ & $1800 \pm 262$ \\
\hline
\end{tabular}

ganic substances (DOM) were measured on filtrate $(0.45 \mu \mathrm{m})$ at $254 \mathrm{~nm}$ with a $5 \mathrm{~cm}$ quartz cell. Total phosphorus (TP), total reactive phosphorus (TRP), nitrate $\left(\mathrm{NO}_{3}\right)$ and ammonia $\left(\mathrm{NH}_{4}\right)$ were determined following methods reported by Hermanowicz et al. (1999). The trophic class was assessed according to Carlson's (1977) classification by the use of $\mathrm{TSI}_{\mathrm{TP}}$ and $\mathrm{TSI}_{\mathrm{Chl}}$.

\section{RESULTS AND DISSCUSION}

Most of studied ponds had an alkaline water $\mathrm{pH}$ with the exception of mid-forest ponds, which were neutral on average. In the chemical composition of the waters a great variability was recorded, which suggested a difference of natural conditions in the surrounding environment. The ponds were well oxygenated, however, relatively lower oxygen concentrations were found in the pastoral ponds. Another sign of the harmful influence of the catchment area on the quality of the investigated pastoral ponds was seen in their higher conductivities and higher concentrations of nitrate and TRP, comparing to the ponds of other groups. A cluster analysis indicate that forest ponds make up a compact group closer to urban ponds, whereas pastoral ponds compose a quite distinct heterogeneous group. The chemistry of waters of mid-forest and urban ponds had a number of common features, especially relating to the concentration of total phosphorus, total reactive phosphorus and ammonium which contributed to the quality distinctiveness of the waters of these water bodies (Fig. 1).

The level of mineralization of waters of the examined ponds was not higher than $1000 \mu \mathrm{S} \mathrm{cm}^{-1}$, and the highest values were obtained in the pas- toral ponds. The concentration of dissolved organic matter (DOM) in these ponds was also a high. Small water bodies located within the city borders were characterised by a lower DOM concentration when compared with the midforest and pastoral (Table 1). A feature of water bodies situated within the agricultural-pastoral area, and also mid-forest had similarly high values of this variable, indicating the high concentrations of organic compounds such as humic substances. Such a situation is typical because in the untrasformed landscape small water bodies are the biogeochemical barriers, which effectively restrict the free migration of mineral and organic substances (Szpakowska \& Życzyńska-Bałoniak, 1994).

Differences in the phytoplankton biomass were related to each group of water bodies (Fig. 2).

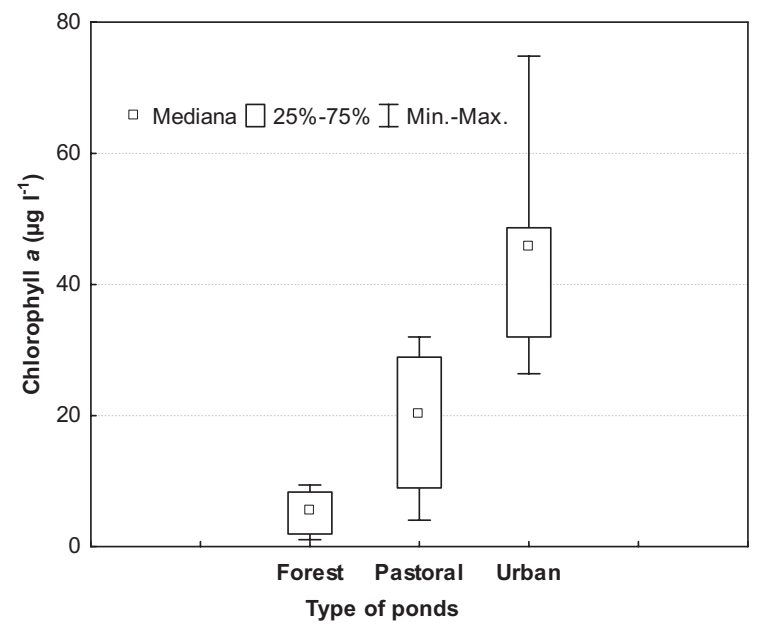

Figure 2. The differentiation of chlorophyll $a$ content in the different types of pond landscapes: forest (I), pastoral (II) and urban (III). Diferenciación del contenido de clorofila a en los distintos tipos de charcas: forestal (I), pastoral (II) y urbano (III). 
Maximum concentrations occurred in the urban ponds $\left(45 \pm 18.8 \mu \mathrm{g}^{-1}\right)$, which indicated favourable conditions for algal development. However, this situation did not lead to the complete depletion of mineral nutrients (Table 1). A notable result of the massive development of algae was the rise in water $\mathrm{pH}$ (mean $\mathrm{pH}$ of 9.0). When the concentration of inorganic carbon is very low in eutrophic waters, a further increase in the water $\mathrm{pH}$ can make the inorganic carbon become a restricting factor for algal development (Gołdyn, 2000). In pastoral and mid-forest ponds the phytoplankton biomass (averages of $16.3 \mu \mathrm{g} \mathrm{l}^{-1}$ and $5.3 \mu \mathrm{g} \mathrm{l}^{-1}$ of chlorophyll $a$ respectively) was considerably lower than in urban ponds. One reason for the weaker development of algae in the pastoral water bodies might have been the result of the inflow of toxic substances during the vegetation period that came from the chemical compounds used for crop protection (Joniak, 2009), such as defoliants in liquid form, which can result in the physiological decomposition of chlorophyll (Szpakowska \& Życzyńska-Bałoniak, 1994).

The concentration of phosphates in particular groups of ponds were considerably differentiated (Table 1). Application of the quotient TRP/TP showed a large disproportion of the contribution of phosphates in the total phosphorus for each type of pond. Comparably low values of TRP/TP in the mid-forest and urban ponds (34\% and $31 \%$ respectively) reflected a depletion of phosphorus sources which, however, occurred in surplus in the pastoral ponds (62\%).

In order to find out the relationships among the variables characterising the physical-chemical features of water within each group of ponds, these variables were analysed using PCA analysis. In each group of ponds the first three principal components explained over $90 \%$ of the observed variation, where about half was explained by the first component (Fig. 3). This axis seems to be related with trophic level in the three groups of ponds. In mid-forest ponds this first component accounted for the variability of the mineral contents in the waters and their dystrophic character. Figure 3 shows that in this group of ponds, $\mathrm{pH}$ is much related to conductivity and that these
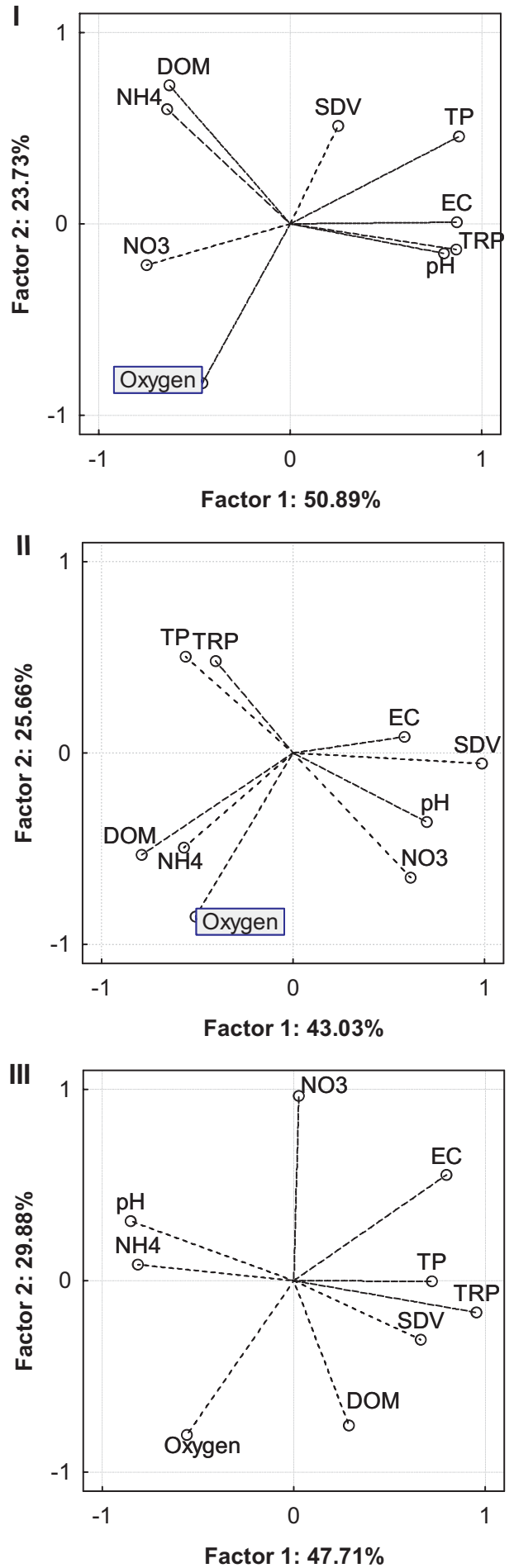

Figure 3. PCA analysis of physical and chemical variables of the water in each of the different groups of ponds, according to land uses: forest (I), pastoral (II) and urban (III). Análisis de componentes principales de las variables físicas y químicas del agua en cada uno de distintos grupos de charcas según los usos del suelo: forestal (I), pastoreo (II) y urbano (III). 
two variables are inversely related to DOM and ammonia, closely placed together. This indicate that principal component 1 accounts for a gradient between dystrophic ponds with an important dependence of allochthonous organic matter versus ponds with higher mineral contents and $\mathrm{pH}$, the just mentioned variables go with phosphorous since less dystrophic ponds are a possibly more productive. In pastoral mid-field ponds the first component separates ponds with high nitrates from those with high DOM and phosphorous, so this component accounts for the variability of ponds with a higher influence of agricultural fields versus those with higher influence of livestock impact. In pastoral ponds SDV had a higher significance, and a higher transparency of the water goes together with higher mineral contents, $\mathrm{pH}$ and nitrates, indicating that ponds with these features had a higher influence from agricultural fields. On the other hand, phosphorous was positioned in the DOM-ammonium side indicating a higher load of organic matter possibly related with stronger cattle impact, indicating a higher trophic level. A very different situation, from the other two groups of ponds, occurs in urban ponds where autogenic production dominates, DOM has a very low correlation with component 1 and it is not related with ammonia, but it is related to productivity indicated by the total phosphorus. In the ponds of this group productivity is determined mainly by phytoplankton growth, this is indicated by their higher chlorophyll content. The high $\mathrm{pH}$ that some of these ponds may reach $(\mathrm{pH} \geq 9)$ induces depletion of inorganic carbon in the form of $\mathrm{CO}_{2}$ and further metabolic activity with the use $\mathrm{HCO}_{3}^{-}$will lead to different biological effects that influence the major sources of variation in these waters (Wetzel, 2001). The second component is more difficult to interpret but may be related to some redox processes since oxygen shows very high loadings in the negative side of the axis 2 in all cases, but variables with high positive loadings are different depending on pond types, indicating dissimilarity of metabolism and functioning between these three groups of ponds.

The trophic conditions of the studied ponds in various types of landscape confirms the much higher supply of the biogenic compounds in the mid-field water bodies, where the average values of $\mathrm{TSI}_{\mathrm{TP}}$ amounted to 82, overgrowing the borders of hypertrophic conditions. In the remaining types of ponds this index accounted for eutrophy. The increase of the eutrophic processes is not a rule in the case of small water bodies, however, it is often accelerated by the inflow of the biogenic substances from the catchment area and by covering the pond bottom with organic sediments (Hongve, 1999). Significantly higher concentrations of chlorophyll in the urban ponds represented the highest values of TSI $_{\text {Chl }}$ (average 67 ), while in the pastoral and mid-forest ponds they were lower (57 and 44 respectively). An interesting feature was connected with the equal level of the $\mathrm{TSI}_{\mathrm{TP}}$ and $\mathrm{TSI}_{\mathrm{Chl}}$ indexes in the urban ponds, in comparison with the higher values of phosphorus index $\mathrm{TSI}_{\mathrm{TP}}$ in the remaining types of ponds. Statistical analysis revealed a lack of significant relationships between chlorophyll and phosphorus as well as between water transparency and chlorophyll. According to Fairchild et al. (2005) this phenomenon indicates the fact that the trophic conditions of small water bodies are controlled by different parameters than those occurring in lakes. In small pond relationships with its catchment area and land uses are higher and much of the phosphorous may be detritic originating from benthic-pelagic coupling and from inflows of allochthonous organic matter. Moreover the very frequent mixing of the waters into the bottom with the resuspension of sediments and the turn-over of the surplus of biogenic substances accumulated in sediments into the water column (Sondergaard et al., 2003).

Nitrogen was mainly represented by nitrates in the pastoral ponds, and by ammonium in midforest and urban ponds (Table 1). These differences reflected the level of landscape transformation and the land use type in the catchment area. In the case of arable landscapes, the use of artificial fertilisers is decisive in the composition of nitrogen compounds leaching to the water of the ponds (Joniak et al., 2006). A dominance of ponds representing a dominance of $\mathrm{NO}_{3}^{-}$ions indicates that the surface and underground flow of waters from soils was a feature responsible for 
the water chemistry. A different situation exists in the case of forest soils, where the drainage of ammonium is considerably higher compared to nitrates (Klimaszyk et al., 2003).

\section{CONCLUSIONS}

1. The research confirmed that the waters of the ponds were a reservoir of inorganic compounds, as well as of dissolved organic matter. The urban and pastoral water bodies, compared with mid-forest ponds, represented conditions of considerably higher mineral salts and nutrients, which was reflected in the values of electric conductivity and concentrations of phosphorus and nitrates.

2. Urban ponds, where anthropogenic pressure was strongest, favoured phytoplankton development (higher concentration of chlorophyll a) compared to ponds located within the forest and pastoral catchment areas. Pastoral mid-field ponds showed a variability depending whether surrounding land uses were agricultural fields or livestock. On the other hand mid-forest ponds could have more or less strong dystrophic characteristics.

\section{ACKNOWLEDGMENTS}

This research work was financed by the Polish State Committee for Scientific Research in 20052009 as research project 2P06S 00829.

\section{REFERENCES}

CARLSON, R. E. 1977. A trophic state index for lakes. Limnol. Oceanogr., 22: 361-369.

FAIRCHILD, G. W., J. N. ANDERSON, \& D. J. VELINSKY. 2005. The trophic state 'chain of relationship' in ponds: does size matter? Hydrobiologia, 539: 35-46.

GOŁDYN, R. 2000. Changes in biological and physico-chemical parameters of river water quality as a result of its damming in preliminary lowland reservoirs. AMU Press, Poznań. 186 pp.

HERMANOWICZ, W., J. DOJLIDO, W. DOŻAŃSKA, B. KOZIOROWSKI, \& J. ZERBE. 1999. The physical-chemical analyses of water and wastewater. Arkady Press, Warszawa. 556 pp.

HONGVE, D. 1999. Production of dissolved organic carbon in forested catchments. J. Hydrol., 224: 9199.

JONIAK, T. 2009. Hydrochemical characteristics of waters and an outline of the chemism of sediments of small water bodies in the pastoral and forest landscape. In: Functioning of plankton communities in habitat differentiated small water bodies of the Wielkopolska area. N. Kuczyńska-Kippen (ed.): 33-59. Bonami Press, Poznań.

JONIAK, T., N. KUCZYŃSKA-KIPPEN, \& B. NAGENGAST. 2006. The chemistry of waters of small water bodies in the agricultural landscape of the western Wielkopolska region. TEKA Kom. Ochr. Kszt. Środ. Przyr., 3: 60-65.

JONIAK, T., B. NAGENGAST, \& N. KUCZYŃSKA-KIPPEN. 2009. Can popular systems of trophic classification be used for small water bodies? Ocean. Hydrobiol. Studies., 38(4): 145-151.

KASPRZAK, P., J. PADISAK, R. KOSCHEL, R. KRIENITZ, \& R. GERVAIS. 2008. Chlorophyll $a$ concentration across of trophic gradient of lakes: An estimator of phytoplankton biomass? Limnologica, 38: 327-338.

KLIMASZYK, P., M. KRASKA, R. PIOTROWICZ, $\&$ T. JONIAK. 2001. Functioning of small water bodies of the Wielkopolska National Park (West Poland). Verh. Internat. Verein. Limnol., 28: 17351738.

KUCZYŃSKA-KIPPEN, N. 2009. Functioning of plankton communities in habitat differentiated small water bodies of the Wielkopolska area. Bonami Press, Poznań. 502 pp.

PACZUSKA, B., R. PACZUSKI, \& E. KRASICKAKORCZYŃSKA. 2002. Mid-field and mid-forest reservoirs at the edge of the Wysoczyzna Świecka (Pojezierze Krajenskie). Microflora, macrophytes and environment. ATR Press, Bydgoszcz. 92 pp.

PREZELIN, B. B., M. M. TILZER, O. SCHOFIELD, \& C. HAESE. 1991. The control of the production processes of phytoplankton by the physical structure of the aquatic environment with special reference to its optical properties. Aquatic Sci., 53, 2/3: 135-186. 
SONDERGAARD, M., J. P. JENSEN, \& E. JEPPESEN. 2003. Role of sediment and internal loading of phosphorus in shallow lakes. Hydrobiologia, 506-509: 135-145.

SZPAKOWSKA, B. \& I. Życzyńska-Bałoniak. 1994.
The role of biogeochemical barriers in water migration of humic substances. Pol. J. Env. Stud., 3, 2: $35-41$.

WETZEL, R. G. 2001. Limnology. W. B. Saunders Co., Philadelphia. 1006 pp. 